\title{
Sharing Tacit Knowledge in an Organizational Context - Different Profiles, Different Strategies
}

Márcio José Sol Pereira Oliveira*

NECE - Research Center in Business Sciences, Higher School of Education and Social Sciences of Leiria - Polytechnic of Leiria, Portugal

DOI: $10.36347 /$ sjebm.2020.v07i12.002

| Received: 26.11.2020 | Accepted: 07.12.2020 | Published: 10.12.2020

*Corresponding author: Márcio José Sol Pereira Oliveira

Abstract

Original Research Article

Focusing the study's on sharing tacit knowledge in non-profit organizations (NPOs) in Portugal and taking as a case study the Portuguese volunteer firefighters (FBs), we listed as objectives ascertaining the profiles of Portuguese volunteer firefighters in the face of sharing tacit knowledge and identify action strategies to be implemented by these organizations, taking into account the different profiles of firefighters. A review of the literature on lessons learned and sharing of tacit knowledge allowed the identification of the main factors and typologies of barriers most prevalent in these organizations. A quantitative study carried out with 380 Portuguese firefighters made it possible to carry out a cluster analysis, which analysis of results made it possible to answer the established objectives. It was possible to identify the presence of 5 clusters distinct from each other, which include firefighters who favor different factors of sharing tacit knowledge and who identify different types of barriers to sharing tacit knowledge. Such scenario refers to different approaches, in the undertaking of efforts to promote the sharing of tacit knowledge, according to the profile of each cluster of firefighters. Studies in this area, aimed at the NPOs are scarce, as opposed to what happens in the private and public sectors. The case study option of organizations such as the Portuguese FBs, unique in their action and identity, accompanies the, increasingly recognized by society, need in enabling these organizations of competences for the best possible performance, in the face of tragic events that have occurred in recent years in Portugal.

Keywords: Tacit knowledge, sharing, profiles, non-profit organizations, strategies.

Copyright $\odot 2020$ The Author(s): This is an open-access article distributed under the terms of the Creative Commons Attribution 4.0 International License (CC BY-NC 4.0) which permits unrestricted use, distribution, and reproduction in any medium for non-commercial use provided the original author and source are credited.

\section{INTRODUCTION}

The sharing of tacit knowledge within organizations, despite the recognition of the benefits that result from it, is not easy to establish as a regular practice. Due to their unique characteristics, the NPOs, in carrying out their missions, are increasingly promoting this sharing. There are few studies that indicate performance matrices, which contain strategies, measures or concrete actions for their promotion. To this end, it becomes a priority to understand the profiles of the human resources of these organizations and to understand which factors of sharing tacit knowledge are most privileged and which types of barriers they identify as the most prevalent.

Starting with these objectives, this article presents the results of an investigation on the sharing of tacit knowledge in Portuguese FBs, a type of NPO that develops its activities in the area of civil protection and pre-hospital emergency. It should be noted that in Portugal there is no other type of organization in which its driving force is composed of a set of purely voluntary elements and collaborators that provide the minimum daily operational services, ensuring the volunteers the night and weekly service, where there is an increased intervention and availability of these elements in the summer season, with a marked decrease in service in the remaining seasons, where the hierarchical structure follows a paramilitary regime, but which may include at the top of its pyramid firefighters who only perform work within the scope of voluntary service operating in a service area as sensitive as civil protection. Due to its unique characteristics, the present study gains relevance and topicality.

Thus, the article begins with a brief introduction to the subject and with the keywords, followed by the theoretical framework, with a focus on factors and typologies of barriers to sharing tacit knowledge. The next point deals with the presentation and discussion of the results. Finally, we present the conclusions and recommendations for future studies. 


\section{LITERATURE REVIEW}

The process of making tacit knowledge is not always a conscious process and some of this knowledge may not even be capable of representation outside the human mind [1]. Sveiby [2] considers tacit knowledge as personal knowledge, and this personal knowledge is difficult to express, formalize or share, existing in an intangible format. Tacit knowledge is rarely shared and communicated because its nature is subjective and intuitive, which leads to an enormous loss, for example, when a very experienced employee leaves the organization to which he belongs [3]. In this regard, Hislop [4] and Mládková [5] tell us that since tacit knowledge is always stored in the human brain, its sharing is difficult, complex, time-consuming and one of the greatest challenges for knowledge management. According to Nonaka and Takeuchi [6], Teece [7] and Ivona [8], about two thirds of the information received in the work context is transformed into tacit knowledge through face-to-face interaction, such as informal conversations, direct interaction, short stories, mentoring, networking or internships, which indicates that this is a complex task, as according to Mongkolajala et al., [9], requires communication between coworkers in order to capture this type of knowledge.

In order to determine the best strategies, measures or actions that aim to increase this sharing of tacit knowledge in an organizational context, more specifically in NPO, it is important to define the different profiles of the individuals that integrate them, in order to better adapt these suggestions. In this sense, the following points are dedicated to the literature review of the main factors and types of barriers, recognized as prevalent in these organizations, and which can influence the different clusters found in the study.

\section{Tacit Knowledge Sharing Factors}

For the present study, the first factor identified is "organizational culture". For this factor, it is considered the dominant recognition and reward system in the organization, which motivates the continuous sharing of tacit knowledge among firefighters [10-12] the promotion of types of training for the task of knowledge sharing that privileges tacit knowledge, and as examples, coaching and mentoring $[13,11,14]$ the transmission of knowledge that is essentially based on personal and informal conversations [6, 14, 15, 13]; knowledge is not seen as a source of power $[10,16,11]$; the prevalence of a favorable environment for questioning [17]; the prevalence of a culture that distinguishes and values individual knowledge or intuitions [18]; a communication system based on verbal communication or conversations between firefighters [14, 12]; and the existence of adequate physical spaces to promote the sharing of tacit knowledge [19].
The second factor identified is "individual characteristics". For this factor, individual time management is considered, which allows firefighters to have moments favorable to this sharing of knowledge $[12,20]$ the use of a common language that allows a way to pass this knowledge on effectively [10, 12, 16 , 11] the predominance of a feeling of mutual trust that reduces uncertainties and mistrust among firefighters and that promotes an environment favorable to the sharing of tacit knowledge $[21,16]$, the availability of a good relationship network that allows each firefighter to know who within the organization has the knowledge he needs to increase his skills and tacit knowledge [10, 22] and the prevalence of a recognition and reward system that motivates firefighters to share this knowledge more [10-12].

The third factor identified is "organizational structure". For this factor, the diagnosis made by the hierarchical structure of the FBs regarding the needs for tacit knowledge that may exist and the availability of the internal relationship network is considered [11, 22]; the proximity between the different elements that make up the hierarchical structure of the FBs, which allows any element, however low that is in that hierarchy and that potentially has less tacit knowledge, to have access to whoever occupies the top positions of that hierarchy, who potentially has tacit knowledge [11, 22]; the availability or promotion of techniques or strategies such as coaching or mentoring, where the sharing of tacit knowledge is privileged and a specific type of training is offered for this sharing task, by the organizational structure $[13,11,14]$, the promotion of informal conversations and personal contacts, which facilitates this sharing of knowledge between firefighters $[6,14,15,13]$ and privileging people as a way of storing knowledge at the expense of databases [15].

\section{Types of barriers to tacit knowledge sharing}

Regarding the barriers to sharing tacit knowledge in an organizational context, it is possible to find 4 types of barriers as the most prevalent: communicational, technological, personal, and resource or infrastructure.

The first type of barrier identified is
communication barriers. Communication is
fundamental for the organization, as Davenport and
Prusak [16] refer. These authors tell us that
communication can be of a verbal or written nature,
while Riege [23] tells us that personal interactions are
fundamental for sharing tacit knowledge. For Jóia and
Lemos [24] organizations with bureaucratic and
hierarchical characteristics are not flexible, and these
characteristics can appear as communication barriers for
this sharing. For Holste and Fields [25] and Reige [23],
internal competitiveness, high turnover, limited
resources, lack of transparency, lack of qualified and


experienced personnel can also constitute barriers to good communication.

The second type of barrier considered in the study is technological barriers. This type of barrier is composed of the following barriers: inadequate information technologies for internal communication, inadequate information technologies, insufficient technical support and insufficient information technologies. Regarding these types of barriers, we can see that they may be inadequate, both for internal communication in FBs and for their needs in general. The possibility of insufficient technical support is another technological barrier, which is also echoed in this study. Insufficient and difficult to use technology, with no potential to improve the performance of firefighters are other barriers pointed out by Riege [23].

The third type of barrier identified in the study is personal barriers, which is based on the individual characteristics of the people who make up the organization, their perceptions, feelings or preferences. It was possible to find 6 subtypes of personal barriers: individual differences, such as different cultural origins, genders, educational levels, generations or ages, languages and levels of experience [27-29, 23], the individual perception of the costs of sharing, where sharing can be seen as an information overload, be considered as an extra or intrusive activity or convey the feeling that what the person does in nothing contributes to the sharing of tacit knowledge [23], the lack of time, to sharing or identifying those who need to receive tacit knowledge $[30,26]$, recognition and reward, with little perception of advantages in sharing tacit knowledge and reduced perception that the effort of this sharing is not recognized or rewarded by the organization [26], the view of others, with lack of satisfaction in seeing their knowledge replicated or lack of feeling of confidence that each element has in relation to what others transmit to it [25] and, finally, the preference for explicit knowledge, privileging social networks or other physical means or because in the last analysis, this sharing is considered to be inconsistent with the organization's objectives [26].

The fourth type of barriers identified is resource or infrastructure barriers, which are divided into two subtypes: presence of formal meaning and structure, where the sharing of tacit knowledge is perceived as incompatible with the organization's objectives, where a strong sense of the hierarchical structure is felt, the fear of sharing and the difficulty of interpersonal relationships [31], and the physical and material resources, seen as physical or material barriers [32].

\section{METHODOLOGY}

For the present investigation, an exploratory methodological approach was adopted, in order to better understand the factors of tacit knowledge sharing and the main types of barriers in the NPO, taking FBs in Portugal as a case study. Based on these factors and types of barriers, a questionnaire was designed to determine the different profiles of firefighters, their different positions in relation to these factors and types of barriers. The questionnaire consisted of two parts, the first consisting of a set of generic questions about the respondent and the second comprising thirteen multiplechoice questions, according to the Likert scale with five response categories, ranging from "totally disagree" to "I totally agree". Each question aimed to determine the degree of agreement on the prevalence of a factor or barrier to the sharing of tacit knowledge.

The FBs were the NPO chosen, due to the voluntary link with which the operational personnel exercises their functions, in an area of action as sensitive as the prevention and provision of fire assistance and all types of accidents. In this regard, it is important to mention that during 2017 two major operational events took place in Portugal in terms of fires, responsible for more than 500 thousand hectares of burnt area, the first between the 17th and 24th of June in the Municipalities of Pedrogão Grande, Castanheira de Pêra, Ansião, Alvaiázere, Figueiró dos Vinhos, Arganil, Góis, Penela, Pampilhosa da Serra, Oleiros and Sertã, where 64 people died and where 490 homes and 50 industrial units burned, and the second between 14 and October 16, over 30 municipalities in the central region of Portugal, where 48 people died and where 521 industrial units burned, responsible for 4500 jobs. These events refocused the importance of the activities of the FBs in the field of civil protection and launched a series of reflections with civil society, which, according to the Report of the Independent Technical Commission for these events, with the need to provide these operational staff with greater knowledge, qualification and the need to adopt best governance practices in the Portuguese forest.

Thus, the respondents chosen were the firefighters from the FBs who anonymously and voluntarily adhered to their completion. In line with the presented, the sample made a total of 380 firefighters. In order to identify and eliminate possible problems with the questionnaire, a pre-test was carried out with 32 firefighters from the Brasfemes FB. The questionnaire was applied using an internet survey tool called Google Forms. Once the data of the 380 respondents were collected, a cluster analysis was carried out which allowed the grouping of five groups of firefighters to be grouped, with similar responses to each other and different from the other groups.

\section{Analysis and discussion of results}

Taking into account the objectives of the present study, a cluster analysis of the collected data was carried out. The Tukey $b$ test analysis follows, which distinguishes 5 clusters for each knowledge sharing factor and for each barrier typology identified in the present study. 
Márcio José Sol Pereira Oliveira., Sch J Econ Bus Manag, Dec, 2020; 7(12): 431-442

Table-1: Tukey $b$ test for factors and types of barrier to sharing tacit knowledge in FBs

\begin{tabular}{|c|c|c|c|c|c|c|c|}
\hline & \multirow{2}{*}{$\begin{array}{l}\text { Cluster case } \\
\text { number }\end{array}$} & \multirow[t]{2}{*}{$\mathbf{N}$} & \multicolumn{4}{|c|}{ Subset for alpha $=0.05$} \\
\hline & & & & 1 & 2 & 3 & 4 \\
\hline \multirow{5}{*}{\multicolumn{2}{|c|}{ Factor: organizational culture }} & 3 & 7 & -2.7379605 & & & \\
\hline & & 2 & 62 & & -.5417645 & & \\
\hline & & 4 & 132 & & -.2078329 & -.2078329 & \\
\hline & & 1 & 89 & & & .1856154 & .1856154 \\
\hline & & 5 & 90 & & & & .7074366 \\
\hline \multirow{5}{*}{\multicolumn{2}{|c|}{ Factor: individual characteristics }} & 4 & 132 & -.7772657 & & & \\
\hline & & 5 & 90 & & .1535299 & & \\
\hline & & 3 & 7 & & .2684655 & & \\
\hline & & 1 & 89 & & .5705152 & & \\
\hline & & 2 & 62 & & .5826818 & & \\
\hline \multirow{5}{*}{\multicolumn{2}{|c|}{ Factor: organizational structure }} & 2 & 62 & -1.0561887 & & & \\
\hline & & 4 & 132 & & -.0450565 & & \\
\hline & & 5 & 90 & & .1771742 & & \\
\hline & & 1 & 89 & & .5395012 & .5395012 & \\
\hline & & 3 & 7 & & & 1.0671257 & \\
\hline \multirow{5}{*}{\multicolumn{2}{|c|}{ Barrier typology: communicational }} & 1 & 89 & -.7679212 & & & \\
\hline & & 5 & 90 & & -.1589339 & & \\
\hline & & 3 & 7 & & .3070486 & & \\
\hline & & 4 & 132 & & .3931882 & & \\
\hline & & 2 & 62 & & .4612719 & & \\
\hline \multirow{5}{*}{\multicolumn{2}{|c|}{ Barrier typology: technological }} & 2 & 62 & -.4706822 & & & \\
\hline & & 4 & 132 & -.3132836 & & & \\
\hline & & 3 & 7 & -.2813060 & & & \\
\hline & & 1 & 89 & .1553843 & .1553843 & & \\
\hline & & 5 & 90 & & .6519518 & & \\
\hline \multirow{30}{*}{$\begin{array}{l}\text { Barrier } \\
\text { typology: } \\
\text { personal }\end{array}$} & \multirow{5}{*}{$\begin{array}{l}\text { Subtype: personal } \\
\text { differences }\end{array}$} & 3 & 7 & -.4422148 & & & \\
\hline & & 1 & 89 & -.3012355 & -.3012355 & & \\
\hline & & 2 & 62 & -.1493338 & -.1493338 & & \\
\hline & & 5 & 90 & -.0032547 & -.0032547 & & \\
\hline & & 4 & 132 & & .2989173 & & \\
\hline & \multirow[t]{5}{*}{ Subtype: sharing costs } & 1 & 89 & -.7178798 & & & \\
\hline & & 2 & 62 & -.5536511 & -.5536511 & & \\
\hline & & 3 & 7 & & -.0444810 & -.0444810 & \\
\hline & & 4 & 132 & & & .2266698 & \\
\hline & & 5 & 90 & & & & .7623181 \\
\hline & \multirow[t]{5}{*}{ Subtype: lack of time } & 3 & 7 & -1.3814691 & & & \\
\hline & & 4 & 132 & & -.0959528 & & \\
\hline & & 5 & 90 & & -.0924029 & & \\
\hline & & 1 & 89 & & .1480180 & & \\
\hline & & 2 & 62 & & .2819147 & & \\
\hline & \multirow{5}{*}{$\begin{array}{l}\text { Subtype: recognition } \\
\text { and reward }\end{array}$} & 3 & 7 & -1.2600209 & & & \\
\hline & & 2 & 62 & -.7022907 & -.7022907 & & \\
\hline & & 4 & 132 & & -.2271259 & & \\
\hline & & 1 & 89 & & & .3898301 & \\
\hline & & 5 & 90 & & & .5294213 & \\
\hline & \multirow[t]{5}{*}{ Subtype: others' view } & 4 & 132 & -.4083457 & & & \\
\hline & & 1 & 89 & .0286880 & & & \\
\hline & & 5 & 90 & .2252032 & & & \\
\hline & & 2 & 62 & .2524896 & & & \\
\hline & & 3 & 7 & & 2.2036780 & & \\
\hline & \multirow{5}{*}{$\begin{array}{l}\text { Subtype: preference for } \\
\text { explicit knowledge }\end{array}$} & 1 & 89 & -.1816640 & & & \\
\hline & & 4 & 132 & -.1633263 & & & \\
\hline & & 2 & 62 & -.0189775 & & & \\
\hline & & 5 & 90 & .2955179 & & & \\
\hline & & 3 & 7 & & 1.7581663 & & \\
\hline
\end{tabular}


Márcio José Sol Pereira Oliveira., Sch J Econ Bus Manag, Dec, 2020; 7(12): 431-442

\begin{tabular}{|c|c|c|c|c|c|c|}
\hline \multirow{10}{*}{$\begin{array}{l}\text { Barrier } \\
\text { typology: } \\
\text { of resources } \\
\text { or } \\
\text { infrastructure }\end{array}$} & \multirow{5}{*}{$\begin{array}{l}\text { Subtype: presence of } \\
\text { formal and structure }\end{array}$} & 2 & 62 & -.7184148 & & \\
\hline & & 5 & 90 & -.4694875 & & \\
\hline & & 1 & 89 & & .3045240 & \\
\hline & & 4 & 132 & & .3463043 & \\
\hline & & 3 & 7 & & & 1.9972553 \\
\hline & \multirow{5}{*}{$\begin{array}{l}\text { Subtype: physical and } \\
\text { material resources }\end{array}$} & 3 & 7 & -.4709485 & & \\
\hline & & 4 & 132 & -.1653585 & -.1653585 & \\
\hline & & 5 & 90 & -.1336623 & -.1336623 & \\
\hline & & 2 & 62 & -.1111745 & -.1111745 & \\
\hline & & 1 & 89 & & .4949033 & \\
\hline
\end{tabular}

Next, the harmonic mean of the Tuckey $b$ test is presented for the cluster analysis carried out previously and which clarifies the factors and typologies of barriers to sharing tacit knowledge in FBs.

Table-2: Results of the harmonic mean of the Tukey $b$ test for the analysis of the 5 clusters

\begin{tabular}{|c|c|c|c|c|c|c|c|c|c|c|}
\hline \multirow{2}{*}{$\begin{array}{l}\text { Factors / Typologies and } \\
\text { Subtype of Barriers to } \\
\text { Sharing Tacit Knowledge }\end{array}$} & \multicolumn{2}{|c|}{$\begin{array}{l}\text { Cluster 1 - } \\
\text { Formal }\end{array}$} & \multicolumn{2}{|c|}{$\begin{array}{l}\text { Cluster 2 - } \\
\text { Empathic }\end{array}$} & \multicolumn{2}{|c|}{$\begin{array}{l}\text { Cluster 3- } \\
\text { Explicit }\end{array}$} & \multicolumn{2}{|c|}{$\begin{array}{l}\text { Cluster } 4 \text { - } \\
\text { Individualists }\end{array}$} & \multicolumn{2}{|c|}{$\begin{array}{l}\text { Cluster 5 } \\
\text { Collectivists } \\
\end{array}$} \\
\hline & $\mathbf{N}$ & $\begin{array}{l}\text { Harmonic } \\
\text { Average }\end{array}$ & $\mathbf{N}$ & $\begin{array}{l}\text { Harmonic } \\
\text { Average }\end{array}$ & $\mathbf{N}$ & $\begin{array}{l}\text { Harmonic } \\
\text { Average }\end{array}$ & $\mathbf{N}$ & $\begin{array}{l}\text { Harmonic } \\
\text { Average }\end{array}$ & $\mathbf{N}$ & $\begin{array}{l}\text { Harmonic } \\
\text { Average }\end{array}$ \\
\hline Organizational Culture Factor & \multirow[t]{13}{*}{89} & .186 & \multirow[t]{13}{*}{62} & -.542 & \multirow[t]{13}{*}{7} & -2.738 & \multirow[t]{13}{*}{132} & -.208 & \multirow[t]{13}{*}{90} & .707 \\
\hline $\begin{array}{l}\text { Individual Characteristics } \\
\text { Factor }\end{array}$ & & .571 & & .583 & & .268 & & -.777 & & .153 \\
\hline Organizational Structure Factor & & .540 & & -1.056 & & 1.067 & & -.450 & & .177 \\
\hline $\begin{array}{l}\text { Communication Barriers - } \\
\text { Communication }\end{array}$ & & -.768 & & .461 & & .307 & & .393 & & -.159 \\
\hline $\begin{array}{l}\text { Technological Barriers - } \\
\text { Technology }\end{array}$ & & .155 & & -.471 & & -.281 & & -.313 & & .652 \\
\hline $\begin{array}{l}\text { Personal Barriers - Personal } \\
\text { Differences }\end{array}$ & & -.301 & & -.149 & & -.442 & & .299 & & -.003 \\
\hline $\begin{array}{l}\text { Personal Barriers - Sharing } \\
\text { Costs }\end{array}$ & & -.718 & & -.554 & & -.044 & & .227 & & .762 \\
\hline $\begin{array}{l}\text { Personal Barriers - Lack of } \\
\text { Time }\end{array}$ & & .148 & & .282 & & -1.381 & & -.096 & & -.092 \\
\hline $\begin{array}{l}\text { Personal Barriers - Recognition } \\
\text { and Reward }\end{array}$ & & .390 & & -.702 & & -1.260 & & -.227 & & .529 \\
\hline $\begin{array}{l}\text { Personal Barriers - View of } \\
\text { Others }\end{array}$ & & .029 & & .252 & & 2.203 & & -.408 & & .225 \\
\hline $\begin{array}{l}\text { Personal Barriers - Preference } \\
\text { for Explicit Knowledge }\end{array}$ & & -.182 & & -.019 & & 1.758 & & -.163 & & .296 \\
\hline $\begin{array}{l}\text { Resource or Infrastructure } \\
\text { Barriers - Presence of formal } \\
\text { and structure }\end{array}$ & & .305 & & -.718 & & 1.997 & & .346 & & -.469 \\
\hline $\begin{array}{l}\text { Resource or Infrastructure } \\
\text { Barriers - Physical and material } \\
\text { resources }\end{array}$ & & .495 & & -.111 & & -.471 & & -.165 & & -.134 \\
\hline
\end{tabular}

From the analysis of the data presented, it is possible to ascertain the existence of 5 clusters of firefighters, with different profiles between them. Due to its characteristics, the following denominations were assigned: cluster 1: formal; cluster 2: empathic; cluster 3: explicit; cluster 4: individualists; cluster 5: collectivists. Next, the composition of each cluster is analyzed, taking into account the factors of tacit knowledge sharing that they privilege and the different types of barriers that they identify as most prevalent in the organizations to which they belong, to the sharing of tacit knowledge. A performance matrix with the main strategies and implementation is also presented for each cluster, in order to promote the sharing of tacit knowledge.

\section{Cluster 1 - Formal}

The first cluster is composed of firefighters who refer to the three factors of tacit knowledge sharing (organizational culture, organizational structure and individual characteristics), as relevant factors for the sharing of tacit knowledge in their FBs. For these firefighters, indicators such as individual time management and the recognition and reward for sharing tacit knowledge are indicators that work as an obstacle to sharing this knowledge, while aspects such as physical space also work as an obstacle to this sharing.

It is important to mention that the types of barriers most mentioned by this group of firefighters are echoed in these factors. For these firefighters, the typology of personal barriers, which include the absence of recognition and reward and the lack of time 
for sharing is referred to as major obstacles to this sharing of tacit knowledge. For these firefighters, the strong sense of presence of the formal and the structure is also mentioned, framing the typology of resource and infrastructure barriers. Even within this type of barrier, cluster 1 firefighters are the only ones to point out, as a barrier to the sharing of tacit knowledge, the inexistence or inadequacy of physical and material resources, thus attaching importance to formal characteristics as a way they privilege to share knowledge. tacit.

Technological barriers are also considered to be significant for cluster 1 firefighters. Communication barriers do not appear to be an obstacle to sharing tacit knowledge.

Thus, it can be considered that cluster 1 includes firefighters who do not clearly distinguish which factors are prevalent in sharing tacit knowledge. This group of firefighters is also unclear as to the types of barriers that most rise to this sharing, just excluding the communicational typology, distinguishing itself from the other clusters by the remarkable relevance they attach to the formal aspects that underlie the sharing of this knowledge. For this privilege to formality, firefighters in this cluster can be classified as formal.

\section{Cluster 2 - Empathic}

The second cluster or group of firefighters identified in the present study is composed of firefighters who exclusively privilege individual characteristics as a factor of sharing tacit knowledge. For these firefighters, the organizational culture and the organizational structure are not relevant factors to this sharing.

Regarding the types of barriers that this group of firefighters most refers to, we can identify communication barriers and personal barriers such as the lack of time for sharing tacit knowledge and the vision of others. For this group of firefighters, there are no relevant resource or infrastructure or technological barriers.

We can thus consider that we are facing a second group of firefighters who, in common, present the fact that they privilege individual characteristics as a factor of choice for sharing tacit knowledge and that point out as typologies of barriers to sharing tacit knowledge, inadequate communication, the lack of time and the vision of the other elements of your FB.

This second group of firefighters differs from the others in that they clearly emphasize the empathic characteristics of other individuals as a success factor for sharing tacit knowledge. Regarding the typologies of barriers, they exclude technological and resource or infrastructure barriers, giving priority to communicational and personal barriers as the ones that rise most against this tacit knowledge sharing. Since the success of sharing is based on individual characteristics and the success of communication, the firefighters of this 2 nd cluster can be considered as empathic.

\section{Cluster 3 - Explicit}

The third cluster, or group of firefighters identified in the present study, is distinguished from the others by privileging the organizational structure as a determining factor for sharing tacit knowledge, that is, they privilege knowledge sharing indicators such as knowledge transmission, hierarchy, the relationship network, the storage of knowledge and the type of training for the task. For these firefighters, the individual characteristics factor has little influence on the sharing of tacit knowledge and the organizational culture factor is not decisive for this sharing.

As for the types of barriers that are most prevalent among cluster 3 firefighters, it should be noted that only technological barriers are not verified at all, that communication barriers are identified as relevant, that among the personal barriers that are identified, the vision prevails of others and the preference for explicit knowledge and among the barriers of resources or infrastructures the strong presence of the formal and the structure is pointed out.

Thus, we can consider that, even though we are facing a cluster composed of relatively few firefighters, which has statistical significance and reveals very specific characteristics, such as the privilege it gives to the explicit characteristics for sharing this knowledge. These characteristics, as the main promoters of tacit knowledge sharing in FBs.

In this sense, consolidating the great difference for the other groups in what are the formal characteristics of the organization, these firefighters can be called explicitizers.

\section{Cluster 4 - Individualists}

The fourth cluster is the largest in the study, with 132 firefighters, and is distinguished from the other groups in that it does not privilege any particular tacit knowledge sharing factor. In the same way that this is noticeable, it is also possible to perceive that the types of barriers that point out as more prevalent are of a different order, since only technological barriers are not mentioned as relevant.

Thus, it is possible to find in cluster 4 , barriers of the communicational, personal and resource or infrastructure type. As for personal barriers, barriers related to personal differences between firefighters and the costs of sharing are mentioned. As for the barriers of resources or infrastructures, it is possible to identify the strong presence of the formal and the structure.

Due to their lack of association with any tacit knowledge sharing factor and the types of barriers that 
identify this knowledge sharing, these firefighters can be considered as individualists.

\section{Cluster 5 - Collectivists}

The fifth cluster is characterized by being the one in which the firefighters that compose it, privilege the organizational culture as a predominant factor for the sharing of tacit knowledge. Despite this prevalence, the other two factors coexist, but with less influence.

In this cluster, technological barriers are also identified as a typology of barrier to knowledge sharing, which is effectively verified. Regarding the types of personal barriers, stands out in this cluster subtypes cost sharing, recognition and reward, the vision of others, and the preference for explicit knowledge.

It is important to add that there are no barriers in the communication type and the type of resources or infrastructure in this cluster.

Because of the focus on organizational culture, this group of firefighters can be called collectivists.

Table-3: Strategies for promoting tacit knowledge sharing for the identified clusters

\begin{tabular}{|c|c|c|c|c|}
\hline \multicolumn{2}{|c|}{ Barrier typology } & Reference authors & $\begin{array}{l}\text { Strategies to promote tacit knowledge } \\
\text { sharing }\end{array}$ & $\begin{array}{l}\text { Target } \\
\text { clusters }\end{array}$ \\
\hline \multicolumn{2}{|c|}{ Communication } & $\begin{array}{lr}\text { Davenport } & \& \\
\text { Prusak (1998) [16]; } & \\
\text { Hendricks } & (1999) \\
\text { [33]; Riege, } & (2007) \\
\text { [26] } & \end{array}$ & $\begin{array}{l}\text { - Guarantee the recruitment of firefighters } \\
\text { with adequate communication skills, in order } \\
\text { to try to get the best out of the firefighters that } \\
\text { the FB already has in its active staff. } \\
\text { - Provide training programs and development } \\
\text { of communication skills appropriate to the FB } \\
\text { activity. } \\
\text { - Support an open communication flow } \\
\text { between all FB organizational levels. } \\
\text { - Encourage people to be open, proactive and } \\
\text { close, without fear of contributing ideas and } \\
\text { opinions. } \\
\text { - Recognize and reward well done } \\
\text { communication. }\end{array}$ & $\begin{array}{l}\text { 2. Empathic } \\
\text { 3. Explicit } \\
\text { 4. } \\
\text { Individualists }\end{array}$ \\
\hline \multicolumn{2}{|c|}{ Technological } & Riege, (2007) [26] & $\begin{array}{l}\text { - To verify if the information technologies are } \\
\text { adequate for internal communication and if } \\
\text { they are the ones effectively necessary to the } \\
\text { needs of the organization. } \\
\text { - Understand if there is a technical support } \\
\text { that corresponds to the needs of the } \\
\text { organization and that offers timely solutions } \\
\text { to operational activities. } \\
\text { - Understand whether information } \\
\text { technologies are sufficient. } \\
\text { - To determine if information technologies } \\
\text { have the potential to improve the performance } \\
\text { of the elements. } \\
\text { - Understand whether information } \\
\text { technologies are difficult to use for users. }\end{array}$ & $\begin{array}{l}\text { 1. Formal } \\
\text { 5. Collectivists }\end{array}$ \\
\hline Personal & $\begin{array}{l}\text { Lack of } \\
\text { time for } \\
\text { sharing }\end{array}$ & $\begin{array}{l}\text { Michailova \& } \\
\text { Husted (2003) [30]; } \\
\text { Riege, (2007) [26] }\end{array}$ & $\begin{array}{l}\text { - Recognize the difficulties of time } \\
\text { availability, share them with the whole } \\
\text { organization and define periods of work break } \\
\text { purposefully so that tacit knowledge sharing } \\
\text { occurs. } \\
\text { - Gather and share "success stories" that } \\
\text { emphasize the importance of transferring tacit } \\
\text { knowledge about explicit knowledge for } \\
\text { individual and organizational learning and } \\
\text { allowing firefighters to recognize time spent } \\
\text { on this tacit knowledge sharing activity. } \\
\text { - Offer or improve existing social or social } \\
\text { areas. }\end{array}$ & $\begin{array}{l}\text { 1. Formal } \\
\text { 2. Empathic }\end{array}$ \\
\hline
\end{tabular}




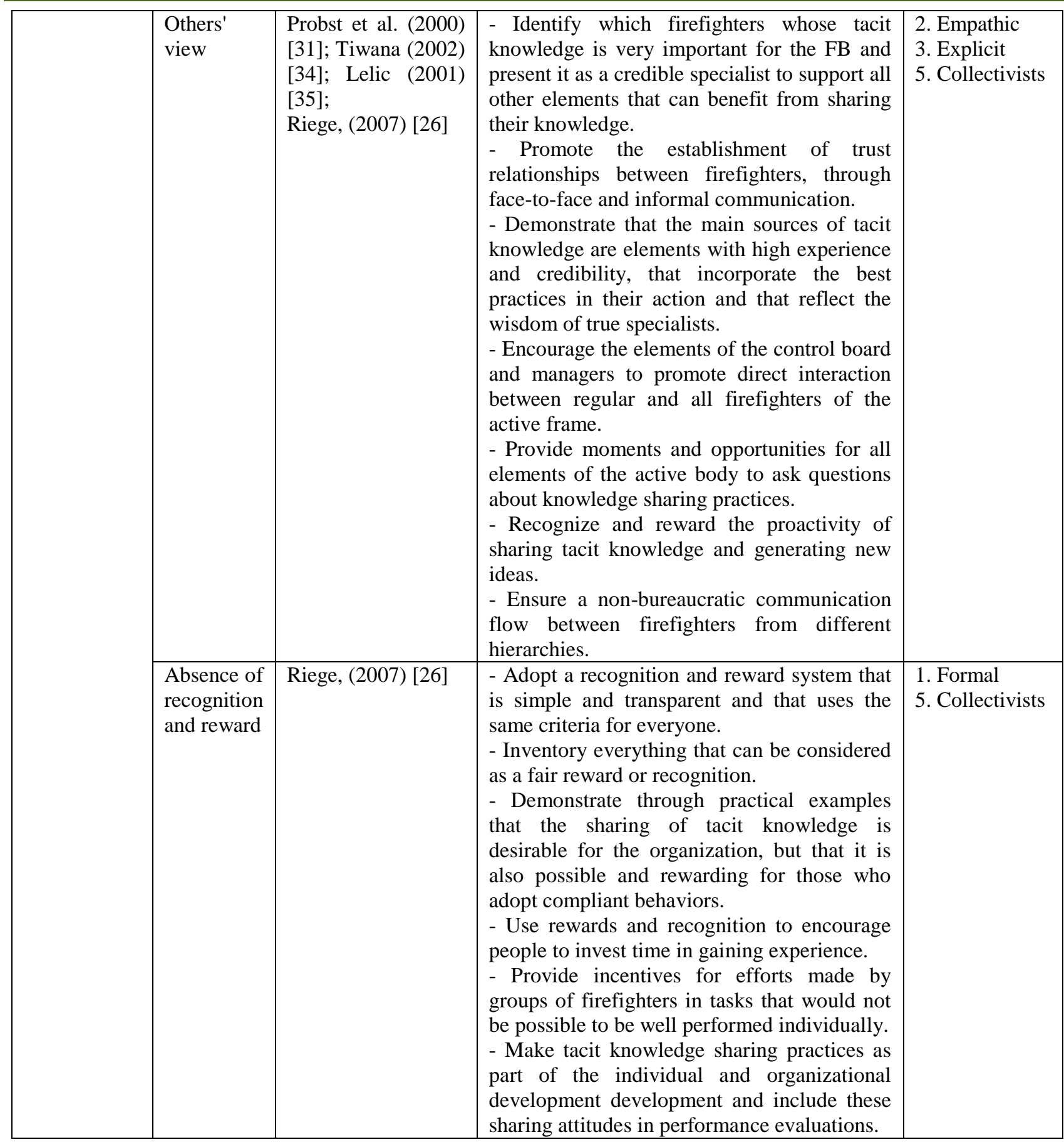




\begin{tabular}{|c|c|c|c|}
\hline $\begin{array}{l}\text { Preference } \\
\text { for explicit } \\
\text { knowledge }\end{array}$ & $\begin{array}{l}\text { Nonaka \& Takeushi } \\
\text { (1995) [6]; O’Dell e } \\
\text { Grayson (1998) } \\
\text { [22]; Riege, (2007) } \\
\text { [26] }\end{array}$ & $\begin{array}{l}\text { - Encourage and promote practical learning } \\
\text { through learning-by-doing, through } \\
\text { observation and dialogue or in an interactive } \\
\text { way between those who teach and those who } \\
\text { learn. } \\
\text { - Increase awareness for the fact that tacit } \\
\text { knowledge cannot be easily transferred, but } \\
\text { that this is possible, demonstrating concrete } \\
\text { ways of doing it and its benefits for } \\
\text { firefighters and the FB. } \\
\text { - Support the networks of stakeholders in } \\
\text { each intervention area, existing inside and } \\
\text { outside the FB, such as in the first aid area, } \\
\text { involving doctors, nurses and firefighters, so } \\
\text { that standards of action can be discussed, } \\
\text { based on best practices and that lead to tacit } \\
\text { knowledge sharing among all stakeholders. } \\
\text { - Emphasize the main means for the transfer } \\
\text { of tacit knowledge, such as experiences, } \\
\text { stories or demonstrations of know-how. }\end{array}$ & $\begin{array}{l}\text { 3. Explicit } \\
\text { 5. Collectivists }\end{array}$ \\
\hline $\begin{array}{l}\text { Personal } \\
\text { differences }\end{array}$ & $\begin{array}{l}\text { Terpstra \& David, } \\
\text { (1991) [29]; } \\
\text { Sveiby \& Simmons, } \\
\text { (2002); Sveiby, } \\
\text { (1997) [2]; Riege, } \\
\text { (2007) [26] }\end{array}$ & $\begin{array}{l}\text { - Improve the understanding of intercultural } \\
\text { differences by promoting these differences as } \\
\text { something enriching for the FB. } \\
\text { - Raise awareness about the tensions related } \\
\text { to gender differences between people and } \\
\text { what losses this can bring to the organization. } \\
\text { - Remove the misperception that higher levels } \\
\text { of education correlate with higher levels of } \\
\text { experience and knowledge. } \\
\text { - Remove the misconception that firefighters } \\
\text { with low levels of formal education do not } \\
\text { need to share or have nothing to contribute } \\
\text { and share. } \\
\text { - Remove the misperception that older ages } \\
\text { correspond to higher levels of experience and } \\
\text { knowledge. } \\
\text { - Provide mentoring and coaching programs } \\
\text { through which the most experienced } \\
\text { firefighters advise and guide the less } \\
\text { experienced firefighters. }\end{array}$ & $\begin{array}{l}4 . \\
\text { Individualists }\end{array}$ \\
\hline $\begin{array}{l}\text { Sharing } \\
\text { costs }\end{array}$ & $\begin{array}{lr}\text { Nonaka } & \& \\
\text { Takeushi, } & (1995) \\
\text { [6]; O'Dell \& } \\
\text { Grayson, }(1998) \\
\text { [22]; Riege, } \\
\text { [26] }\end{array}$ & $\begin{array}{l}\text { Simplify the knowledge sharing } \\
\text { mechanisms, using tools and natural } \\
\text { processes, familiar to firefighters, that are } \\
\text { consistent and in accordance with the style of } \\
\text { activity they perform, such as, carrying out } \\
\text { simulations in the places referred to as most } \\
\text { likely to happen certain type of occurrence, in } \\
\text { the territory under FB's own jurisdiction. } \\
\text { - Identify and eliminate tasks that lead to } \\
\text { wasted time or that are of low value to the } \\
\text { organization, replacing those moments with } \\
\text { others dedicated to sharing tacit knowledge. } \\
\text { - If there is an absolute need for a longer } \\
\text { period of time or hours of service to be spent } \\
\text { by the fireman so that he can enjoy the } \\
\text { moments established for sharing tacit } \\
\text { knowledge, recognizing and rewarding that } \\
\text { time. }\end{array}$ & $\begin{array}{l}\text { 4. } \\
\text { Individualists } \\
\text { 5. Collectivists }\end{array}$ \\
\hline
\end{tabular}




\begin{tabular}{|c|c|c|c|c|}
\hline \multirow[t]{2}{*}{$\begin{array}{l}\text { Of resources } \\
\text { or } \\
\text { infrastructure }\end{array}$} & $\begin{array}{l}\text { Presence } \\
\text { of formal } \\
\text { and } \\
\text { structure }\end{array}$ & \multirow[t]{2}{*}{$\begin{array}{l}\text { De Long \& Fahey, } \\
\text { (2000) [36]; Riege, } \\
\text { (2007) [26] }\end{array}$} & $\begin{array}{l}\text { - Reduce the strong sense of the hierarchical } \\
\text { structure, implementing a more "flat" } \\
\text { structure and a flexible structure capable of } \\
\text { creating a team spirit. } \\
\text { - Implement measures to combat the } \\
\text { individual or collective fear of sharing, for } \\
\text { fear of error or punishment. }\end{array}$ & $\begin{array}{l}\text { 1. Formal } \\
\text { 3. Explicit } \\
\text { 4. } \\
\text { Individualists }\end{array}$ \\
\hline & $\begin{array}{l}\text { Absence or } \\
\text { inadequacy } \\
\text { of physical } \\
\text { and } \\
\text { material } \\
\text { resources }\end{array}$ & & $\begin{array}{l}\text { - Limit the number or size of formal groups to } \\
\text { a small size, with a view to maximizing the } \\
\text { activities to implement it in relation to the } \\
\text { sharing of tacit knowledge. } \\
\text { - Provide formal and informal spaces and } \\
\text { moments, giving firefighters opportunities to } \\
\text { share tacit knowledge in social situations, } \\
\text { such as at social events, gym, cafeteria, bar, } \\
\text { social room, among others. } \\
\text { - Design the redefinition of spaces in the } \\
\text { areas of work, learning and socializing, so } \\
\text { that they contribute to a timely sharing of } \\
\text { tacit knowledge. } \\
\text { - Position workplaces, learning and } \\
\text { socializing in order to promote interaction } \\
\text { between firefighters, from different positions } \\
\text { in the hierarchical structure and with different } \\
\text { levels of knowledge and experience. }\end{array}$ & 1. Formal \\
\hline
\end{tabular}

\section{CONCLUSIONS AND RECOMMENDATIONS}

In order to identify the profiles of volunteer firefighters, a cluster analysis was carried out, which allowed the identification of 5 different groups, with 5 different firefighter profiles as to their position in relation to the factors and types of barriers. It is possible to conclude that for each of the three factors of tacit knowledge sharing (organizational culture, individual characteristics and organizational strategy), there is a cluster of firefighters that privileges it to the detriment of the others. There is also a cluster that does not favor any of these factors, while the opposite is also true, therefore there is a cluster that highlights the three factors of tacit knowledge sharing in an identical way.

To each of these clusters, it is possible to associate a factor or a set of factors of sharing of tacit knowledge and some types and subtypes of barriers, whose firefighters that constitute the clusters recognize and identify as more prevalent.

In this way, it can be considered that the first cluster includes formal firefighters, who do not clearly distinguish which factors are prevalent in sharing tacit knowledge. This cluster of firefighters is also unclear as to the types of barriers that most rise to this sharing, just excluding the communicational typology.

The second cluster of firefighters, composed of empathic firefighters, differs from the others in that they clearly privilege individual characteristics as a success factor for sharing tacit knowledge. Regarding the typologies of barriers, they exclude technological and resource or infrastructure barriers, giving priority to communicational and personal barriers as the ones that rise most against this tacit knowledge sharing. Since the success of sharing is based on individual characteristics and the success of communication, the firefighters of this 2 nd cluster can be considered as empathic.

The third cluster of firefighters, composed of the explaining firefighters, clearly privileges the organizational structure as a decisive factor for the sharing of tacit knowledge, and they still attach some importance to the individual characteristics of the elements of the FB for this success. Regarding the types of barriers that are most prevalent in this cluster of firefighters, they are essentially of a personal, communicational nature and of resources and infrastructure.

Cluster 4 firefighters, called individualists, are distinguished from the other clusters because they do not privilege any tacit knowledge sharing factor. They do not consider technological barriers as obstacles to the sharing of tacit knowledge, but rather the other types. Due to their lack of association with any tacit knowledge sharing factor, these firefighters can be considered as individualists.

The last cluster is made up of firefighters called collectivists and is distinguished from the other clusters since they clearly privilege the organizational culture factor as the preferred factor for sharing tacit knowledge, even though they recognize the importance of the other factors. Regarding the types of barriers, they do not consider communication barriers or those of 
resources or infrastructures, as being crucial to the sharing of tacit knowledge, but they attach importance to personal and technological barriers. Because of the focus on organizational culture, this cluster of firefighters can be called collectivists.

For each of these clusters, taking into account the factors of sharing tacit knowledge that they privilege and the types of barriers they refer to as the most prevalent, it was possible to move forward with a performance matrix with performance strategies in order to increase the sharing of this knowledge tacit in these organizations.

Finally, in order to broaden the spectrum of studies centered on the sharing of tacit knowledge in the NPO according to the profiles of the individuals that compose them, it is recommended to carry out other studies in organizations such as associations, cooperatives, private institutions of social solidarity, mutual associations, foundations, among others that are becoming increasingly more important in society.

\section{REFERENCES}

1. Oliveira M, Pinheiro P. Factors in the Sharing of Tacit Knowledge among Volunteer Firefighters. International Journal of Business and Management, 2019; 14(1), 54-64.

2. Sveiby K. The new organizational wealth: managing and measuring knowledge- based assets, Berrett-Koehler, San Francisco. 1997.

3. Othman A, Abdullah $\mathrm{H}$. The Influence of Emotional Intelligence on Tacit Knowledge Sharing in Service Organizations, In Minwir AlShammari (Ed.), Knowledge Management in Emerging Economies: Social, Organizational and Cultural Implementation: 2010; 171-185.

4. Hislop D. Knowledge management in organizations: a critical introduction. London, Oxford: Oxford University Press. 2013.

5. Mládková L. Sharing Tacit Knowledge within Organizations: Evidence from the Czech Republic, Global Journal of Business Research, 2012; 6(2): 105-115. Web: http://dx.doi.org/10.41 35/9781446217375

6. Nonaka I, Takeuchi H. The knowledge creating company: how Japanese companies create the dynamics of innovation. Oxford: Oxford University Press. 1995.

7. Teece D. Managing Intellectual Capital: Organizational, Strategic, and Policy Dimensions, Oxford University Press, New York, NY. 2000.

8. Ivona $\mathrm{O}$. The Importance of Tacit Knowledge Within the Organization, 2009; 414-416. Web: http://steconomice.uoradea.ro/anale/volume/2009/ v4-management-andmarketing/73.pdf.

9. Mongkolajala H, Panichpathom S, Ngarmyarn A. The Development of Tacit Knowledge Sharing behavior among Employees in Organizations,
International Journal of Business and Social Research, 2012; 2(5):158-163.

10. Szulanski G. Exploring Internal stickiness: impediments to the transfer of best practice within the firm, Strategic Management Journal, 1996; 17:27-43.

11. Disterer G. Fostering knowledge sharing: why and how?, IADIS International Conference E-Society, 2003, Lisbon. 2003.

12. Haldin-Herrgard T. Difficulties in the Diffusion of Tacit Knowledge in Organizations, Journal of Intellectual Capital, 2000; 1(4):357-365.

13. Jóia L. Knowledge Management Strategies: Creating and Testing a Measurement Scale, International Journal of Learning and Intellectual Capital, 2007; 4(3):203-221. http://dx.doi.org/10.1504/IJLIC.2007.015607

14. Leonard D, Sensiper S. The role of tacit knowledge in group innovation, California Management Review, 1998; 40(3):112-25.

15. Hansen M, Nohria N, Tierney T. What's your strategy for managing knowledge?. Harvard Business Review, 1999; 1-10.

16. Davenport T, Prusak L. Working Knowledge: How Organizations Manage What They Know, Harvard Business School Press, Boston, MA, USA. 1998.

17. Sun, P, Scott J. An investigation of barriers to knowledge transfer, Journal of Knowledge Management, 2005; 9(2):75-90. http://dx.doi.org/10.1108/13673270510590236

18. Lemos B, Jóia LA. Relevant factors for tacit knowledge transfer within organizations: an exploratory study, Gestão \& Produção, 2012; 19(2):233-246.

19. Young M. Why educators must differentiate knowledge from experience?, Journal of the Pacific Circle Consortium for Education, 2010; 22(1):9-20.

20. Fahey L, Prusak L. The eleven deadliest sins of knowledge management, California Management Review, 2001; 40(3):265-276.

21. Roberts J. From Know-How to Show-How: Questioning the Role of Information and Communication Technologies in Knowledge Transfer, Technology Analysis and Strategic Management, 2000; 12(4): 429-443.

22. O'Dell C, Grayson C. If only we knew what we know: identification and transfer of internal best practices, California Management Review, 1998; 40(3):154-174.

23. Riege A. Three-Dozen Knowledge-Sharing Barriers Managers Must Consider, Journal of Knowledge Management, 2005; 9(3):18-35.

24. Joia L, Lemos B. Relevant Factors for Tacit Knowledge Transfer Within Organizations, Journal of Knowledge Management, 2010; 14(3):410-427.

25. Holste J, Fields D. Trust and tacit knowledge sharing and use, Journal of Knowledge 
Management, $\quad 2010 ; \quad 14(1): 128-140$. https://doi.org/10.1108/13673271011015615

26. Riege A. Actions to overcome knowledge transfer barriers in MNCs", Journal of Knowledge Management, 2007; 11(1):48-67.

27. McDermott R, O’Dell C. Overcoming culture barriers to sharing knowledge, Journal of Knowledge Management, 2001; 5(1):76-85

28. Sveiby K, Simons R. Collaborative climate and effectiveness of knowledge work, Journal of Knowledge Management, 2002; 6(5):420-33.

29. Terpstra V, David K. The Cultural Environment of International Business, 3rd ed., South-Western Publishing, Cincinnati, OH. 1991.

30. Michailova S, Husted K. Knowledge-sharing hostility in Russian firms, California Management Review, 2003; 45(3):59-77.
31. Probst G, Raub S, Rombhardt K. Managing Knowledge, John Wiley \& Sons, Chichester. 2000.

32. Gold A, Malhotra A, Segars A. Knowledge management: an organizational capabilities perspective, Journal of Management Information Systems, 2001; 18(1), 185-214.

33. Hendricks P. Why share knowledge? The influence of ICT on the motivation for knowledge sharing, Knowledge and Process Management, 1999; 16(2), 91-100.

34. Tiwana A. The Knowledge Management Toolkit, Prentice-Hall, Upper Saddle River, NJ, 2002; 19(4), 53.

35. Lelic S. Creating a knowledge-sharing culture, Knowledge Management, 2001; 4(5), 6-9.

36. De Long D, Fahey L. Diagnosing cultural barriers to knowledge management, Academy of Management Executive, 2000; 14(4), 113- 127. 